\title{
Use of Gibberellic Acid for Management of Bunch Rot on Chardonnay and Vignoles Grape
}

Bryan Hed, Department of Plant Pathology, Pennsylvania State University, Lake Erie Regional Grape Research and Extension Center, North East 16428; and Henry K. Ngugi and James W. Travis, Department of Plant Pathology, Pennsylvania State University, Fruit Research and Extension Center, Biglerville 17307

\begin{abstract}
Hed, B., Ngugi, H. K., and Travis, J. W. 2011. Use of gibberellic acid for management of bunch rot on Chardonnay and Vignoles grape. Plant Dis. 95:269-278.

Harvest bunch rot of wine grape, caused primarily by Botrytis cinerea, is a perennial problem limiting the productivity of eastern vineyards, especially on cultivars with compact clusters. The aim of the present study was to evaluate the effectiveness of gibberellic acid (GA) sprays at reducing the compactness of Chardonnay and Vignoles clusters and minimizing bunch rot. Applications of GA reduced the number of berries per centimeter and the incidence and severity of bunch rots in Vignoles and, to a lesser extent, in Chardonnay over three consecutive years; however, the magnitude of GA effects often depended on the timing and rate of application. Bloom GA applications were more effective $(P<0.001)$ at reducing compactness and bunch rots than prebloom applications. Significantly, negative effects of GA applications on yield were negligible based on data from 4 years of trials on single vines and 2 years of data on 24-vine plots of Vignoles, provided

ries per centimeter accounted for between 89 and $94 \%$ of variation in the incidence of Botrytis rot on Vignoles. On Chardonnay, compactness accounted for $53 \%$ of the variation in incidence, and the estimated compactness level at which no bunch rot would occur was $4.40 \pm 1.05$ (mean \pm standard error) berries per centimeter. The relationship between cluster compactness and spray coverage of berries was also investigated in two separate experiments. Spray coverage of individual berries decreased linearly as cluster compactness increased within the range tested ( 3 to 18 berries per centimeter). Cluster compactness accounted for two-thirds of the variation in individual berry coverage, and coverage was reduced by 40 to $50 \%$ for clusters with about 18 berries per centimeter. These results strongly support the use of GA in integrated management of bunch rot on Vignoles and Chardonnay in eastern U.S. vineyards.
\end{abstract} the rates did not exceed $25 \mathrm{ppm}$. Regression analysis showed that ber-
Harvest bunch rot complex of wine grape is a perennial diseasemanagement challenge in Eastern viticulture that can severely impact wine quality $(13,20)$. Grape cluster rots tend to be most difficult to control in cultivars that produce compact bunches such as Vitis vinifera Chardonnay, Pinot noir, and Riesling and the Vitis interspecific hybrid Vignoles. Fungicides and cultural controls for bunch rot often increase production costs by hundreds of dollars per hectare, depending on cultivar and season. In trials at the Lake Erie Regional Grape Research and Extension Center, losses to bunch rot have averaged about 10 and $20 \%$ per year on Chardonnay and Vignoles, respectively, but losses as high as $40 \%$ have been observed. Previous research has described the relationship between cluster compactness and bunch rot development in $V$. vinifera cultivars $(29,35)$. Recently, we documented the relationship between cluster compactness and bunch rot in Vitis interspecific hybrid Vignoles and showed that reducing cluster tightness resulted in lower bunch rot incidence and severity on that cultivar (13). It has also been shown that methods that reduce cluster compactness can reduce severity of harvest bunch rots in other cultivars (35).

Several methods, including application of gibberellic acid (GA), have been investigated over the years as a means for cluster loosening. Research carried out over 50 years ago established that prebloom and bloom applications of GA can reduce the compactness and predisposition to bunch rot of several important grape cultivars grown in California $(5,6,18,31,32,34)$. More recently, due to "lower yield expectations for higher wine quality" (27), GA is being examined in cooler climate regions of Europe as a means of

Corresponding author: H. K. Ngugi, E-mail: hkn3@psu.edu

Accepted for publication 15 October 2010.

doi:10.1094/PDIS-05-10-0382

(C) 2011 The American Phytopathological Society reducing compactness and bunch rots of high-value seeded wine grape cultivars $(23,26,27)$. However, little has been done to determine the effects of GA in the wetter, more humid regions of the eastern United States, especially among Vitis interspecific hybrid cultivars that make up the foundation of the eastern wine grape industry. Moreover, although these early studies provided strong evidence indicating that GA application reduces the severity of bunch rot, and although GA is labeled for prebloom use on wine grape, its integration into management of harvest bunch rots in the eastern United States remains limited, presumably because there were serious concerns about the detrimental effects of GA application on yield, and also probably because effects on cluster loosening were variable.

There are conflicting reports about the effects of GA applications on yield of wine grape, and the outcomes are often specific to rate, timing, and cultivar. On Riesling, for example, Blaha (1) concluded that GA use was impractical after "high doses" (100 ppm) resulted in shot berry formation and yield reduction. By contrast, Nagao et al. (19) reported the positive effects of much lower rates $(1,5$, and $10 \mathrm{ppm})$ and made no mention of any negative effects on this cultivar. Dass and Randhawa (8) reported adverse effects from high (up to $100 \mathrm{ppm}$ ) post-bloom GA applications to the seeded $V$. vinifera cvs. Bharat Early and Black Hamburg but not to Bhokri. On the other hand, GA application at 1 to 3 weeks after bloom with as much as $200 \mathrm{ppm}$ to the seeded French-American hybrid Golden Queen did not affect fruit set, cluster or berry weights, seed number, or fruit quality (7). Similar applications (50 to $100 \mathrm{ppm}$ at fruit set) to V. labrusca 'Concord' increased fruit set and yield $(2,11)$. The use of GA prebloom (10 and $25 \mathrm{ppm}$ ) on Vitis interspecific hybrid Aurore caused no detrimental effects and was suggested as a potentially beneficial addition to fungicides in an integrated bunch rot control program (21). More recently, GA applied at bloom to Pinot noir in Switzerland at 10 to $100 \mathrm{ppm}$ reduced cluster compactness (particularly at 50 and $100 \mathrm{ppm}$ ), significantly reduced Botrytis and sour rots, and was more effective than two 
Botrytis spp.-specific fungicide applications. There were no effects on bunch fertility in the following years, and no observed effects on shoot growth, vine vigor, or wine composition, although overall yield was significantly reduced by 50 and $100 \mathrm{ppm}$ (27).

The Vitis interspecific hybrid Vignoles is an important cultivar to the eastern U.S. wine grape industry $(12,15-17,24)$. V vinifera Chardonnay, a cultivar of worldwide importance $(28,30)$, is also cultivated in many wine-growing regions of the eastern United States. Both cultivars produce very compact clusters that are highly susceptible to bunch rot disease, and may benefit from applications of GA. However, concerns over potential crop loss and injury to vines have greatly limited the use of GA on these cultivars in eastern viticulture.

In this study, we applied GA to vines of Vitis interspecific hybrid Vignoles and V. vinifera Chardonnay over 3 years in field trials in Pennsylvania. Different rates of prebloom applications were compared with bloom applications for efficacy against bunch rot, and cluster and yield effects. The specific objectives were to (i) determine the effects of GA on cluster compactness and bunch rot development on these cultivars, (ii) evaluate the current season and long-term effects of GA treatment on yield of these cultivars, and (iii) examine the hypothesis that reduction in cluster compactness from GA treatments would improve fungicide penetration and efficacy against bunch rot.

\section{Materials and Methods}

Grapevine cultivars and vineyard set up. Field trials were carried out using mature $V$. vinifera Chardonnay and Vitis interspecific hybrid Vignoles grapevines at the Lake Erie Regional Grape Research and Extension Center in northwestern Pennsylvania. Chardonnay grapevines grafted onto C3309 rootstock were planted in 1999 and trained to a four-cane kniffen trellis system. Vine spacing was $1.8 \mathrm{~m}$ within the row and $2.75 \mathrm{~m}$ between rows. Experiments with Vignoles were carried out in single-vine or 24-vine plots planted in 1999 and 1990, respectively. Mature own-rooted Vignoles grapevines were trained to a single high wire no-tie system, with vine spacing established at $1.8 \mathrm{~m}$ within the row and $2.75 \mathrm{~m}$ between rows for single-vine plots or 2.5 by $2.75 \mathrm{~m}$ for 24 -vine plots.

Single-vine plots. Experiments in the single-vine plots were carried out over a period of 3 years for Chardonnay and 4 years for Vignoles from 2006 to 2009. Experimental treatments consisted of three rates of GA $(5,10$, or $25 \mathrm{ppm})$ applied either 2 to 3 weeks prebloom or at full-to-late bloom, and compared with two Botrytis spp.-specific fungicide treatments and a nontreated control. An additional treatment consisting of a higher rate of GA (40 ppm) was applied at full to late bloom to Vignoles only. The two Botrytis spp.-specific fungicide treatments consisted of plots treated with (i) only the standard two-spray program (with the first fungicide applied just prior to cluster closure and the second at veraison); this standard treatment was also applied to all plots, including those treated with GA, except for the nontreated control; or (ii) a fourspray program consisting of the two-spray program plus two additional sprays, with one at full bloom and another just prior to harvest. The Botrytis spp.-specific fungicides used for these treatments were cyprodinil applied as Vangard 75 WG (Syngenta Crop Protection Inc., Greensboro, NC) at a rate of $0.7 \mathrm{~kg} / \mathrm{ha}$ during full bloom and at veraison, and fenhexamid applied as Elevate 50 WDG (Arysta LifeScience, San Francisco, CA) at $1.1 \mathrm{~kg} / \mathrm{ha}$ during cluster closure and preharvest phenological stages. A fourth year of GA application (2009) was made to Vignoles only, to examine cumulative effects on yield from repeated treatment of the same vines with GA. Only the highest rates of GA application $(25 \mathrm{ppm}$ prebloom and 25 and $40 \mathrm{ppm}$ at bloom) were tested in 2009.

GA was applied as ProGibb 4\% in the 2006 and 2009 experiments or as ProGibb 40\% (Valent BioSciences, Libertyville, IL) in the 2007 and 2008 experiments. GA treatments were applied to runoff with a backpack sprayer at 30 psi with a total volume of 935 liter/ha or about 1,200 to 1,400 liters/ha required for the prebloom and bloom applications, respectively. ProGibb $4 \%$ was applied with a surfactant (Tween 20 at $0.05 \%$, vol $/ \mathrm{vol}$ ), whereas ProGibb $40 \%$ was applied without surfactant.

For Vignoles, GA prebloom treatments were applied on 5 June 2006, which was 14 days prior to trace bloom; 6 June 2007, about 8 days prior to trace bloom; and 7 June 2008, which was 9 days prior to trace bloom. Bloom treatments were applied on 23 June 2006, 20 June 2007, 23 June 2008, and 29 June 2009, when vines were at 50 to $80 \%$ capfall stage. For Chardonnay, GA prebloom treatments were applied on 1 June 2006 (16 days prior to trace bloom), 6 June 2007 (8 days prior to trace bloom), and 7 June 2008 (9 days prior to trace bloom). Bloom treatments were applied on 21 June (50 to $80 \%$ capfall); 20 June (50 to $80 \%$ capfall), and 23 June (50 to $80 \%$ capfall) in 2006,2007 , and 2008 , respectively. The experiment was set up in randomized complete blocks with eight and five replications for Vignoles and Chardonnay plots, respectively. Treatments in this single-vine plot experiment were applied to the same vines each year.

Twenty-four vine plots. This large-plot experiment was designed to evaluate the effects of GA application on yield. Treatment plots consisted of 24 vines each in a 0.4-ha block of mature Vitis interspecific hybrid Vignoles in 2007 and 2008. Experimental treatments evaluated consisted of two rates of GA ( 5 and $10 \mathrm{ppm}$ in 2007 and 10 and 20 ppm in 2008), compared with the standard two-spray, and the four-spray fungicide programs as described for the single-vine plots experiments. GA applications were carried out at full bloom, which had proved to be the most effective time for treatments intended to reduce compactness and rot based on the 2006 single-vine study. GA (ProGibb 40\%) and Botrytis spp.-specific fungicides cyprodinil (Vangard $75 \mathrm{WG}$ ) and fenhexamid (Elevate $50 \mathrm{WDG}$ ) were applied with a Friend covered-boom plot sprayer (Friend Manufacturing Corp., Gasport, NY) at a pressure of 100 psi in 935 liters/ha. Botrytis spp.-specific fungicide applications were made at four stages of grapevine development, as in the single-vine plots, on 20 June, 6 July, and 13 and 28 August 2007 and on 25 June, 11 July, 13 August, and 4 September 2008. GA was applied without a surfactant at bloom on 20 June 2007 and 24 June 2008, when vines were in capfall stage. The experimental design was a randomized complete block design with four replications. Treatments were applied to the same vines each year of the experiment with one exception: vines receiving GA at $5 \mathrm{ppm}$ in 2007 received 20 ppm in 2008.

Plot maintenance and management of other diseases. In all plots, powdery and downy mildew, black rot, and Phomopsis fruit rot were controlled with standard fungicides applied to all vines with a Kinkelder (2006; Kinkelder, Zevenaar, Holland) or a Berthoud (2007 to 2009; Berthoud, Belleville, France) air-blast sprayer. Applications were applied with sprayers calibrated to deliver 470 liters/ha during the prebloom period and 935 and 750 liters/ha for the Kinkelder and Berthoud sprayers, respectively, during the post-bloom period. The fungicides used, formulation, rate per hectare, and date of application are presented in Table 1.

Determination of treatment effects on cluster compactness and bunch rot. Just before harvest, the incidence (percent clusters infected), and severity (percent area infected) of Botrytis bunch rot (Botrytis spp. only) and total rot (Botrytis cinerea plus rots caused by other fungi: Rhizopus, Aspergillus, and Penicillium spp.) were determined from 25 or 100 clusters per plot for the single-vine and 24-vine plots, respectively. Severity was rated using the HorsfallBarratt scale (14) and values were converted to percent area infected using Elanco conversion tables (25). Data on individual cluster effects (cluster length, berries/cluster, berry and rachis weight, and berries per centimeter [compactness]) were determined from 10 clusters per plot that were removed at harvest, frozen, and stored at $-20^{\circ} \mathrm{C}$ for later analysis. To determine cluster effects, all berries were removed and counted for each cluster and the length of main rachis was measured from the first lateral (below the shoulder, if there was one) down to the bottom of the rachis. Separate counts were recorded for the main rachis and shoulder or wing for each cluster. Cluster compactness was determined as the number of berries on the main rachis divided by the length of the main rachis. 
Relationship between cluster compactness and spray coverage. The relationship between cluster compactness and spray coverage of berries was investigated on Vignoles in two experiments that were carried out in 2002 and 2005, and repeated in 2009. Just prior to veraison, clusters were sprayed with either Surround WP (Engelhard Corporation, McIntyre, GA) or spray paint (Ace Hardware Corporation, Oak Brook, IL) and subsequently dissected to obtain data on berries per centimeter, as described above, and percent spray coverage per cluster. Surround WP (60 g/liter) was applied to whole vines in the field at a rate of 935 liters/ha using a Kinkelder in 2002 or at a rate of 750 liters/ha using a Berthoud air-blast sprayer in 2009. To apply the spray paint, clusters were removed from vines, suspended singly along a horizontal wire, and hand sprayed from an aerosol can until all exterior surfaces were thoroughly covered in paint. In each year, clusters used for the experiment were visually selected to represent a broad range of compactness. In total, 48 clusters were used each year in the experiment with Surround while 28 and 44 clusters were used in 2005 and 2009, respectively, in the experiment with spray paint. Percent spray coverage was determined by visually estimating the percentage area of each berry covered by either the spray paint or the Surround powder and calculating a mean value for each cluster.

Current-season and cumulative effects of GA treatment on yield. To investigate effects of applying GA on the same vines over several years, data on yield-related variables were collected from the single-vine plots from 2006 to 2009. In 2006 (i.e., year one), the single-vine plots were not pruned to any specific number of buds but were initially selected for good health and uniformity of size. However, in order to examine potential cumulative effects of GA on fruit yield parameters, vines in all single-vine treatments were pruned at dormant stage to roughly the same number of buds in 2007, 2008, and 2009. Specifically, an average of 60 to 70,50 to 60 , and 55 to 65 buds per vine were retained in the 2007, 2008, and 2009 seasons, respectively. To determine effects on yield-related variables, all Vignoles clusters were removed at harvest, counted, and weighed to record total yield and number of clusters per vine, and to calculate individual cluster weight, grams of fruit per bud, and the number of clusters per bud. Additionally, the number of clusters formed per shoot a year after the GA treatment was determined from 10 randomly selected shoots per vine in 2007 and from 20 shoots in 2008 and 2009. Among 24-vine plots, yield data were collected in both years of the experiment. Vines used for the experiment in the plots were not pruned to a specific number of buds; instead, the crop load was set according to the discretion of an experienced vineyard worker retained from a commercial vineyard near Lake Erie, PA. At harvest, 100 randomly selected clusters were hand picked and weighed to determine mean cluster weight. Subsequently, all clusters were hand picked and immediately weighed in the field to determine total yield (kilograms) per plot.

Statistical analysis. To assess the effects of GA application rate and time of application and the long-term effects of repeated GA treatments on the same vines, data on cluster compactness and harvest rots (Botrytis bunch rot for Chardonnay or total harvest rot for Vignoles) variables were analyzed with the MIXED procedure of SAS software (SAS Institute Inc., Cary, NC). The lsmeans and estimate statements were used to compare treatment means, with separations based on Fisher's protected least significant difference at $\alpha=0.05$ or 0.01 as indicated in the tables. To investigate the relationship between cluster compactness and bunch rot incidence, the means and standard errors of total rot for Vignoles or Botrytis bunch rot incidence for Chardonnay were plotted against those of berries per centimeter for respective treatments. Linear regression analysis was used to determine the relationship between these variables and to determine whether data from different years resulted in different slopes. Preliminary regression analysis indicated significantly different slopes for each year of study for Vignoles but not for Chardonnay. Based on this outcome, data from Chardonnay were combined and a single regression model fitted to assess the relationship between compactness and bunch rot incidence; data for different years from Vignoles were separated before completing linear regression analysis for each data set. To determine the relationship between cluster compactness and spray coverage, the percentage of berries covered with Surround or spray paint was regressed against berries per centimeter. For each spray method, separate regressions were fitted for data obtained in different years.

\section{Results}

Can GA applications reduce cluster compactness in Chardonnay and Vignoles grape? GA applications consistently reduced cluster compactness, measured as berries per centimeter, in all 3 years of testing (Tables 2 and 3). The timing of applications had a significant impact on the reduction of cluster compactness, whereby bloom applications were superior to prebloom applications in all 3 years (Tables 2 and 3). In Chardonnay, compactness was significantly $(P<0.01)$ reduced by prebloom GA applications of 10 and 25 ppm in 2006, 25 ppm in 2007, and by all bloom applications in 2006 and 2007 but only the 25 ppm bloom application was effective in 2008 (Table 2). In Vignoles, only the high rate at prebloom $(25 \mathrm{ppm})$ significantly reduced compactness in all 3 years but all bloom applications significantly reduced compactness in all 3 years (Table 3 ).

Can GA treatments reduce bunch rot incidence and severity? On Chardonnay, nearly all harvest bunch rot in the 3 years of

Table 1. Fungicides and application dates used in the maintenance programs for control of powdery mildew, downy mildew, black rot, and Phomopsis fruit rot on Chardonnay and Vignoles grapevines from 2006 to 2009 in Erie, PA $^{\mathrm{x}}$

\begin{tabular}{|c|c|c|c|c|c|c|c|}
\hline \multicolumn{2}{|l|}{2006} & \multicolumn{2}{|c|}{2007} & \multicolumn{2}{|r|}{2008} & \multicolumn{2}{|c|}{2009} \\
\hline Date & Fungicides & Date & Fungicides & Date & Fungicides & Date & Fungicides \\
\hline \multicolumn{8}{|c|}{ Prebloom sprays } \\
\hline$\ldots$ & $\ldots$ & $\ldots$ & $\ldots$ & 24 April & Calc & 27 April & Calc \\
\hline$\ldots$ & $\ldots$ & $\ldots$ & $\ldots$ & 13 May & $\operatorname{Man}^{y}$ & 25 May & $\operatorname{Man}^{\mathrm{y}}$, Fen \\
\hline 5 June & Kres, $\operatorname{Man}^{\mathrm{z}}$ & 30 May & Fen, $\operatorname{Man}^{\mathrm{y}}$ & 26 May & Man'y, Myclo & 5 June & Man', Para \\
\hline 15 June & Teb, $\operatorname{Man}^{\mathrm{z}}$ & 6 June & Teb, Man ${ }^{\mathrm{z}}$, Phos & 8 June & Man ${ }^{\mathrm{y}}$, Quin & 16 June & Man $^{\mathrm{y}}$, Fen \\
\hline \multicolumn{8}{|c|}{ Post-bloom sprays } \\
\hline 26 June & Quin, $\operatorname{Man}^{2}$, Phos & 18 June & Quin, $\mathrm{Man}^{\mathrm{z}}$, Phos & 22 June & 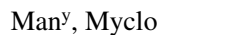 & 28 June & Man'y, Quin \\
\hline 11 July & Teb, Ziram, Phos & 27 June & Teb, Man' & 7 July & Phos, Fen & 13 July & Man', Fen \\
\hline 24 July & Quin, Phos & 9 July & Para, Ziram & 21 July & Quin, Phos, Ziram & 28 July & Phos, Quin \\
\hline 4 August & Quin, Sulfur, Phos & 23 July & Quin, Phos & 31 July & Monopot, Phos, Fen & 10 August & Pot \\
\hline$\ldots$ & ... & 12 September & Phos & 28 August & Phos, Sulfur & 25 August & Phos \\
\hline
\end{tabular}

${ }^{\mathrm{x}}$ Potassium bicarbonate (Pot) was applied as Armicarb (2.8 kg/ha); tebuconazole (Teb) as Elite or Orius (280 g/ha); phosphorous acid (Phos) as Fosphite, Prophyt, or Topaz ( $0.30 \%$ solution); paraffinic oil (Para) as JMS stylet oil (1.50\% solution); calcium polysulfate (Calc) as lime sulfur solution (10\%); sulfur as Microthiol (4.5 kg/ha); monopotassium phosphate (Monopot) as Nutrol (7.9 kg/ha); quinoxyfen (Quin) as Quintec (292 ml/ha); myclobutanil (Myclo) as Rally (280 g/ha); fenarimol (Fen) as Rubigan or Vintage (292 ml/ha); kresoxim-methyl (Kres) as Sovran (280 g/ha); ziram as Ziram (4.5 kg/ha); and mancozeb (Man) as Penncozeb.

${ }^{y}$ Mancozeb at $3.4 \mathrm{~kg} / \mathrm{ha}$.

${ }^{\mathrm{z}}$ Mancozeb at $4.5 \mathrm{~kg} / \mathrm{ha}$. 
the study was caused by Botrytis spp. with very little contribution from other rot organisms. When compared with the unsprayed check, two Botrytis spp.-specific fungicide applications alone (the sprayed check) were not sufficient to significantly reduce the incidence of Botrytis bunch rot in any year, although a reduction in Botrytis disease severity was noted in 2006 (Table 2). However, the use of two additional fungicide sprays (i.e., the four-fungicide with an additional spray at bloom and another preharvest) significantly improved control of bunch rot, reducing both the incidence and severity over the sprayed and unsprayed check, in every year (Table 2). On Chardonnay, the effects of GA treatments were somewhat less consistent than those of the two additional fungicides but mostly resulted in significantly improved Botrytis spp. control. On the one hand, most GA treatments did not reduce the incidence of Botrytis disease over that of the sprayed check, except for the bloom application at 5 or $10 \mathrm{ppm}$ in 2007 and the prebloom application at 5 or $25 \mathrm{ppm}$ in 2008. On the other hand, the GA treatments improved the effectiveness of the sprayed check, resulting in significant control of rot incidence when compared with the unsprayed check. For example, significant reductions in Botrytis disease incidence were achieved in 2006 by all GA treatments and by all but the 5 and $10 \mathrm{ppm}$ prebloom applications in 2007 relative to the nontreated check. Likewise, in 2008, significant reductions in the incidence of bunch rot on this cultivar were observed for all GA treatments except the $10 \mathrm{ppm}$ rate regardless of the time of application (Table 2). The severity of Botrytis rot on Chardonnay was significantly reduced over the sprayed check by GA bloom applications at 5 and $25 \mathrm{ppm}$ in 2006, by prebloom GA at $25 \mathrm{ppm}$ and all bloom GA applications in 2007, and by prebloom GA at 5 and 25 ppm and bloom GA at 5 ppm in 2008 (Table 2). Indeed, all GA treatments, with the exception of the 5- and 10-ppm rates applied prebloom in 2007, reduced Botrytis disease severity to levels statistically equivalent to the two additional Botrytis spp. fungicides program.

On single-vine plots of Vignoles, bunch rot organisms other than Botrytis spp. comprised 8 to $58 \%$ of the total rot severity (data not shown); thus, Table 3 shows the means of total rot instead of Botrytis bunch rot. Non-Botrytis rots generally made up the lowest percentage of the total rot in treatments receiving GA at $25 \mathrm{ppm}$ at bloom (15, 8, and $11 \%$ in 2006, 2007, and 2008, respectively) and the highest percentage of the total rot in treatments relying solely on four Botrytis spp.-specific fungicide applications (44, 58, and $20 \%$ in 2006, 2007, and 2008, respectively). For this reason, Botrytis spp.-specific fungicide sprays were less effective on Vignoles than Chardonnay for overall bunch rot control. Similar to Chardonnay, the two-fungicide spray program (sprayed check) did not reduce total rot incidence on Vignoles in any year or reduce total rot severity in 2 of the 3 years (2006 and 2007) relative to the nontreated control (Table 3 ). The program with two additional fungicide sprays did not reduce the incidence of total rot on Vignoles relative to the nontreated control in 2006 and 2008, and did not reduce rot severity in 2006. Moreover, this additional fungicide program did not significantly improve control of total rots over that obtained from the sprayed check in any year (Table 3 ).

Table 2. Effect of gibberellic acid $\left(\mathrm{GA}_{3}\right)$ and fungicides on berries per centimeter (Bpcm), and the incidence (Incid) and severity (Sev) of Botrytis bunch rot on Chardonnay grape over 3 years (2006-2008)

\begin{tabular}{|c|c|c|c|c|c|c|c|c|c|c|c|}
\hline \multirow{2}{*}{\multicolumn{2}{|c|}{$\begin{array}{l}\text { Treatments } \\
\text { GA }(\mathrm{ppm})^{\mathrm{y}}\end{array}$}} & \multirow[b]{3}{*}{ Fungic $^{\mathrm{z}}$} & \multicolumn{9}{|c|}{ Year of study ${ }^{x}$} \\
\hline & & & \multicolumn{3}{|c|}{2006} & \multicolumn{3}{|c|}{2007} & \multicolumn{3}{|c|}{2008} \\
\hline PB & Bloom & & Bpcm & Incid & Sev & Bpcm & Incid & Sev & Bpcm & Incid & Sev \\
\hline 5 & 0 & $* / \mathrm{E} / \mathrm{V} / *$ & $12.70 \mathrm{ab}$ & $43.2 \mathrm{bc}$ & $6.77 \mathrm{bc}$ & $13.41 \mathrm{ab}$ & $54.4 \mathrm{a}$ & $6.73 \mathrm{ab}$ & $12.79 a b$ & $28.8 \mathrm{~cd}$ & $2.13 \mathrm{c}$ \\
\hline 10 & 0 & $* / \mathrm{E} / \mathrm{V} / *$ & $11.36 \mathrm{bcd}$ & $31.5 \mathrm{bc}$ & $3.82 \mathrm{bc}$ & $12.66 \mathrm{abc}$ & $48.6 \mathrm{ab}$ & $5.88 \mathrm{abc}$ & $12.89 \mathrm{ab}$ & $43.2 \mathrm{abc}$ & $3.88 \mathrm{abc}$ \\
\hline 25 & 0 & $* / \mathrm{E} / \mathrm{V} / *$ & $11.69 \mathrm{bc}$ & $36.8 \mathrm{bc}$ & $5.13 b c$ & $11.33 \mathrm{bcd}$ & $29.0 \mathrm{bc}$ & $1.71 \mathrm{~cd}$ & $12.50 \mathrm{ab}$ & $24.0 \mathrm{~cd}$ & $1.20 \mathrm{c}$ \\
\hline 0 & 5 & $* / \mathrm{E} / \mathrm{V} / *$ & $10.36 \mathrm{~cd}$ & $29.7 \mathrm{bc}$ & $2.84 \mathrm{c}$ & $10.80 \mathrm{bcd}$ & $21.4 \mathrm{c}$ & $0.76 \mathrm{~d}$ & $12.03 \mathrm{ab}$ & $32.8 \mathrm{bcd}$ & $1.65 \mathrm{c}$ \\
\hline 0 & 10 & $* / \mathrm{E} / \mathrm{V} / *$ & $10.78 \mathrm{bcd}$ & $40.8 \mathrm{bc}$ & $3.37 b c$ & $10.59 \mathrm{~cd}$ & $24.0 \mathrm{c}$ & $1.90 \mathrm{bcd}$ & $11.92 \mathrm{ab}$ & $36.8 \mathrm{abcd}$ & $2.81 \mathrm{bc}$ \\
\hline 0 & 25 & $* / \mathrm{E} / \mathrm{V} / *$ & $9.56 \mathrm{~d}$ & $28.8 \mathrm{bc}$ & $2.15 \mathrm{c}$ & $9.17 \mathrm{~d}$ & $29.6 \mathrm{bc}$ & $1.78 \mathrm{~cd}$ & $10.84 \mathrm{~b}$ & $32.0 \mathrm{bcd}$ & $2.73 \mathrm{bc}$ \\
\hline 0 & 0 & $* / \mathrm{E} / \mathrm{V} / *$ & $13.81 \mathrm{a}$ & $52.0 \mathrm{ab}$ & $7.95 \mathrm{~b}$ & $15.10 \mathrm{a}$ & $50.0 \mathrm{ab}$ & $7.09 \mathrm{a}$ & $14.05 \mathrm{a}$ & $48.8 \mathrm{ab}$ & $5.95 \mathrm{ab}$ \\
\hline 0 & 0 & $* / * / * / *$ & $\ldots$ & $68.0 \mathrm{a}$ & $17.43 \mathrm{a}$ & $\ldots$ & $60.0 \mathrm{a}$ & $6.34 \mathrm{a}$ & $\ldots$ & $56.0 \mathrm{a}$ & $7.47 \mathrm{a}$ \\
\hline 0 & 0 & $\mathrm{~V} / \mathrm{E} / \mathrm{V} / \mathrm{E}$ & $\ldots$ & $23.0 \mathrm{c}$ & $2.37 \mathrm{c}$ & $\ldots$ & $12.0 \mathrm{c}$ & $0.77 \mathrm{~d}$ & $\ldots$ & $19.2 \mathrm{~d}$ & $1.55 \mathrm{c}$ \\
\hline
\end{tabular}

${ }^{x}$ Means with the same letter are not significantly different according to Fisher's protected least significant difference $(\alpha=0.05)$. For Bpcm, no compactness data were recorded from $* / * / * / *$ and $\mathrm{V} / \mathrm{E} / \mathrm{V} / \mathrm{E}$ treatments because there was no expectation of effects on compactness from fungicides.

y Concentration of gibberellic acid (GA) in parts per million at prebloom (PB) and bloom.

${ }^{\mathrm{z}}$ Botrytis spp.-specific fungicides applied at bloom/precluster closure/veraison/preharvest, where $\mathrm{E}=$ Elevate at $1.1 \mathrm{~kg} / \mathrm{ha}$ and $\mathrm{V}=\mathrm{Vangard}$ at $0.7 \mathrm{~kg} / \mathrm{ha}$; $*$ indicates no fungicide was applied.

Table 3. Effect of gibberellic acid $\left(\mathrm{GA}_{3}\right)$ and fungicides on berries per centimeter (Bpcm) and the incidence (Incid) and severity (Sev) of total bunch rot (Botrytis, Rhizopus, Penicillium, and Aspergillus spp.) on Vignoles grape over 3 years (2006-2008)

\begin{tabular}{|c|c|c|c|c|c|c|c|c|c|c|c|}
\hline \multirow{2}{*}{\multicolumn{2}{|c|}{ 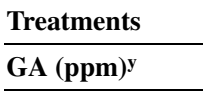 }} & \multirow[b]{3}{*}{ Fungic $^{z}$} & \multicolumn{9}{|c|}{ Year of study $^{x}$} \\
\hline & & & \multicolumn{3}{|c|}{2006} & \multicolumn{3}{|c|}{2007} & \multicolumn{3}{|c|}{2008} \\
\hline PB & Bloom & & Bpcm & Incid & Sev & Bpcm & Incid & Sev & Bpcm & Incid & Sev \\
\hline 5 & 0 & $* / \mathrm{E} / \mathrm{V} / *$ & $9.73 \mathrm{ab}$ & $59.9 \mathrm{bcd}$ & $14.46 \mathrm{~cd}$ & $11.25 \mathrm{a}$ & $69.5 \mathrm{ab}$ & $16.80 \mathrm{ab}$ & $11.69 \mathrm{~b}$ & $75.5 \mathrm{ab}$ & $12.99 \mathrm{bcd}$ \\
\hline 10 & 0 & $* / \mathrm{E} / \mathrm{V} / *$ & $10.54 \mathrm{a}$ & $77.5 \mathrm{a}$ & $16.55 \mathrm{bc}$ & $11.04 \mathrm{ab}$ & $61.8 \mathrm{abc}$ & $14.48 \mathrm{bc}$ & $13.46 \mathrm{a}$ & $80.5 \mathrm{a}$ & $16.95 \mathrm{~b}$ \\
\hline 25 & 0 & $* / \mathrm{E} / \mathrm{V} / *$ & $9.23 \mathrm{~b}$ & $62.4 \mathrm{abc}$ & $10.43 \mathrm{de}$ & $9.30 \mathrm{~cd}$ & $46.5 \mathrm{de}$ & $8.83 \mathrm{c}$ & $10.85 b c$ & $70.0 \mathrm{~b}$ & $11.02 \mathrm{cde}$ \\
\hline 0 & 5 & $* / \mathrm{E} / \mathrm{V} / *$ & $8.77 \mathrm{~b}$ & $59.5 \mathrm{bcd}$ & $10.76 \mathrm{cde}$ & $9.78 \mathrm{bc}$ & $48.5 \mathrm{cde}$ & $10.77 b c$ & $10.95 \mathrm{bc}$ & $69.3 \mathrm{bc}$ & $10.45 \mathrm{de}$ \\
\hline 0 & 10 & $* / \mathrm{E} / \mathrm{V} / *$ & $7.56 \mathrm{c}$ & $45.5 \mathrm{de}$ & 7.01 ef & $9.69 \mathrm{bc}$ & $53.5 \mathrm{cde}$ & $11.54 \mathrm{bc}$ & $10.02 \mathrm{c}$ & $59.5 \mathrm{~cd}$ & 7.48 ef \\
\hline 0 & 25 & $* / \mathrm{E} / \mathrm{V} / *$ & $7.01 \mathrm{~cd}$ & $50.0 \mathrm{cde}$ & $8.15 \mathrm{def}$ & $9.38 \mathrm{~cd}$ & $43.0 \mathrm{e}$ & $9.14 \mathrm{c}$ & $10.15 b c$ & $55.0 \mathrm{de}$ & $5.46 \mathrm{f}$ \\
\hline 0 & 40 & $* / \mathrm{E} / \mathrm{V} / *$ & $6.14 \mathrm{~d}$ & $34.0 \mathrm{e}$ & $4.55 \mathrm{f}$ & $8.24 \mathrm{~d}$ & $59.5 \mathrm{bcd}$ & $12.36 \mathrm{bc}$ & $8.31 \mathrm{~d}$ & $45.5 \mathrm{e}$ & $5.98 \mathrm{f}$ \\
\hline 0 & 0 & $* / \mathrm{E} / \mathrm{V} / *$ & $10.51 \mathrm{a}$ & $77.5 \mathrm{a}$ & $23.63 \mathrm{ab}$ & $11.71 \mathrm{a}$ & $69.0 \mathrm{ab}$ & $17.27 \mathrm{ab}$ & $13.40 \mathrm{a}$ & $76.5 \mathrm{ab}$ & $15.06 \mathrm{bc}$ \\
\hline 0 & 0 & $* / * / * / *$ & $\ldots$ & $78.5 \mathrm{a}$ & $26.82 \mathrm{a}$ & $\ldots$ & $76.0 \mathrm{a}$ & $23.65 \mathrm{a}$ & $\ldots$ & $81.0 \mathrm{a}$ & $22.76 \mathrm{a}$ \\
\hline 0 & 0 & $\mathrm{~V} / \mathrm{E} / \mathrm{V} / \mathrm{E}$ & $\ldots$ & $71.6 \mathrm{ab}$ & $23.10 \mathrm{ab}$ & $\ldots$ & $59.0 \mathrm{bcd}$ & $10.30 \mathrm{bc}$ & $\ldots$ & $74.5 \mathrm{ab}$ & $13.66 \mathrm{bcd}$ \\
\hline
\end{tabular}

${ }^{x}$ Means with the same letter are not significantly different according to Fisher's Protected LSD $(\alpha=0.05)$. For Bpcm, no compactness data were recorded from $* / * / * / *$ and $\mathrm{V} / \mathrm{E} / \mathrm{V} / \mathrm{E}$ treatments because there was no expectation of effects on compactness from fungicides.

y Concentration of gibberellic acid (GA) in parts per million at prebloom (PB) and bloom.

${ }^{\mathrm{z}}$ Botrytis spp.-specific fungicides applied at bloom/precluster closure/veraison/preharvest, where $\mathrm{E}=$ Elevate at $1.1 \mathrm{~kg} / \mathrm{ha}$ and $\mathrm{V}=\mathrm{Vangard}$ at $0.7 \mathrm{~kg} / \mathrm{ha}$; $*$ indicates no fungicide was applied. 
On Vignoles, combining GA treatments with two fungicide applications generally resulted in greater improvement in control of total rots than the use of two additional fungicides, especially in relatively wet years like 2006 and 2008. Total rot incidence was reduced by prebloom GA application at $5 \mathrm{ppm}$ and all bloom sprays relative to the nontreated control in 2006. In 2007, prebloom GA application at $25 \mathrm{ppm}$ and all rates of GA applied at bloom significantly reduced the incidence of rot relative to the nontreated check; only bloom applications of GA at a rate of 10 , 25 , or $40 \mathrm{ppm}$ reduced rot incidence in 2008 (Table 3). The GA bloom applications at 10, 25, or 40 ppm in 2006 and 2008 and 25 ppm in 2007 were superior to two extra fungicides for reduction of total rot incidence. Effects of GA applications on total rot severity in general mirrored those on rot incidence. Total rot severity was significantly reduced over the unsprayed check, sprayed check, and two extra fungicides by all GA treatments in 2006, with the exception of $10 \mathrm{ppm}$ prebloom. In 2007, total rot severity was reduced over the unsprayed and sprayed checks by GA at $25 \mathrm{ppm}$, either at prebloom or bloom, but none of the GA treatments was more effective than two extra fungicides. In 2008, all bloom GA applications reduced total rot severity over the unsprayed and sprayed checks, and applications at 10,25 , and $40 \mathrm{ppm}$ were significantly more effective than two extra fungicides. The most consistently effective treatment was GA at $25 \mathrm{ppm}$ at bloom, which significantly improved control of total rot incidence and severity over the sprayed check and two extra fungicides in every year, except in 2007, when it provided control equivalent to that obtained from the two additional fungicides program (Table 3).

Within the large 24-vine plots of Vignoles, GA treatments at 10 ppm and two extra Botrytis spp.-specific fungicide applications significantly reduced Botrytis disease incidence and severity and total rot severity when compared with the sprayed check (two fungicides alone) in 2007. Of the two GA treatments, only the higher rate of $10 \mathrm{ppm}$ GA reduced total rot incidence when compared with the sprayed check (Table 4). In 2008, only the two additional fungicides program significantly $(P<0.05)$ reduced Botrytis disease incidence and severity and total rot severity when compared with the sprayed check. However, the level of total rot observed in the plots treated with two additional fungicide sprays was not statistically lower than that in the GA-treated plots (Table 4).

Do reductions in cluster compactness account for reduced incidence of bunch rot? Regression analysis indicated strong relationships between cluster compactness and Botrytis bunch rot incidence, especially on Vignoles (Fig. 1). However, the relationship between the incidence of Botrytis disease $(y)$ and cluster compactness $(x)$ had to be described by separate regressions because the slopes significantly $(P<0.001)$ differed every year (Fig. 1A-C). On Chardonnay, the relationship between the incidence of Botrytis rot and cluster compactness could be described with a single model in all 3 years (Fig. 1D). Based on the $R^{2}$ values of these models, berries per centimeter, on average, accounted for between 89 and 94\% of the variation in Botrytis disease incidence on Vignoles and $53 \%$ on Chardonnay. In Chardonnay, the model predicts that no Botrytis rot will develop in clusters with less than about $4.4 \pm 1.05$ berries per centimeter.

Relationship between cluster compactness and spray coverage. In general, the two experiments investigating the effects of cluster compactness on spray coverage gave similar results. In both experiments (Surround WP and spray paint) and in all years, spray coverage increased as cluster compactness decreased. The relationship between spray coverage and berries per centimeter in all experiments was described by linear regression models (Fig. 2). Based on these models, the coverage with Surround WP improved by about $3 \%$ with each drop in berries per centimeter, and the compactness of clusters accounted for about two-thirds of the variation in spray coverage. In experiments utilizing the spray paint, compactness accounted for 46 and $73 \%$ of the variation in spray coverage in the 2005 and 2009 experiments, respectively (Fig. 2). For both experiments, the relationship was linear within the range of compactness of our sample (about 3 to 18 berries per centimeter), and coverage was reduced to about 40 to $50 \%$ as a maximum compactness of 18 berries per centimeter was approached (Fig. 2). However, the relationship would not be expected to be linear across the entire population of clusters; further increases in compactness would eventually result in a flattening of the slope as penetration approaches zero and coverage becomes limited entirely to the outside surfaces of the cluster (data not shown).

Do GA applications negatively affect yield in Vignoles? The effects of GA treatments on yield were investigated in the singlevine plots and the large 24-vine plots. On 24-vine plots of Vignoles, total plot weight (yield in kilograms) and individual cluster weight (g) were not affected by GA or two extra fungicides in either of the 2 years the experiment was carried out (Table 4). The effects of GA application on yield-related variables in the singlevine plots experiments are summarized in Table 5. Vines in the single-vine plots of Vignoles were adjusted to similar bud numbers during dormant pruning and did not significantly differ in the number of buds per vine at the beginning of years 2,3 , or 4 . Compared with the nontreated check, there were no reductions in the number of clusters per bud or per shoot after 2 and 4 years of GA application; however, these two parameters were significantly increased by some GA applications after 3 years of treatment $(P<0.0001$; Table 5; Fig. 3). There were never any discernable cumulative treatment effects on total number of clusters per vine or grams of fruit produced per bud throughout the experiment (Table 5). As with the 24-vine plots, GA treatments had no effects on total plot

Table 4. Effect of gibberellic acid $\left(\mathrm{GA}_{3}\right)$ application on yield, Botrytis rot, and total rot incidence and severity in large plots of Vignoles grape in 2007 and 2008 near Lake Erie, PA $^{w}$

\begin{tabular}{|c|c|c|c|c|c|c|c|}
\hline GA $(\mathbf{p p m})^{\mathrm{x}}$ & Fungicides ${ }^{y}$ & $\begin{array}{l}\text { Plot weight } \\
\text { (kg) }\end{array}$ & $\begin{array}{c}\text { Cluster weight } \\
\text { (g) }\end{array}$ & $\begin{array}{c}\text { Botrytis } \\
\text { incidence (\%) }\end{array}$ & $\begin{array}{c}\text { Botrytis } \\
\text { severity }(\%)^{\mathrm{z}}\end{array}$ & $\begin{array}{c}\text { Total rot } \\
\text { incidence }(\%)\end{array}$ & $\begin{array}{c}\text { Total rot } \\
\text { severity }(\%)^{\mathrm{z}}\end{array}$ \\
\hline \multicolumn{8}{|l|}{2007 crop } \\
\hline 5 & $* / \mathrm{E} / \mathrm{V} / *$ & $158.4 \mathrm{a}$ & $115.6 \mathrm{a}$ & $54.3 \mathrm{~A}$ & $12.4 \mathrm{ab}$ & $67.3 \mathrm{~A}$ & $15.5 \mathrm{ab}$ \\
\hline 10 & $* / \mathrm{E} / \mathrm{V} / *$ & $153.2 \mathrm{a}$ & $115.5 \mathrm{a}$ & $42.5 \mathrm{C}$ & $8.3 \mathrm{c}$ & $56.5 \mathrm{~B}$ & $11.7 \mathrm{~b}$ \\
\hline 0 & $\mathrm{~V} / \mathrm{E} / \mathrm{V} / \mathrm{E}$ & $173.5 \mathrm{a}$ & $120.1 \mathrm{a}$ & $49.3 \mathrm{~B}$ & $10.3 \mathrm{bc}$ & $66.3 \mathrm{~A}$ & $14.2 \mathrm{~b}$ \\
\hline 0 & $* / \mathrm{E} / \mathrm{V} / *$ & $152.8 \mathrm{a}$ & $115.7 \mathrm{a}$ & $57.3 \mathrm{~A}$ & $15.0 \mathrm{a}$ & $70.3 \mathrm{~A}$ & $18.5 \mathrm{a}$ \\
\hline \multicolumn{8}{|l|}{2008 crop } \\
\hline 20 & $* / \mathrm{E} / \mathrm{V} / *$ & $188.8 \mathrm{a}$ & $140.5 \mathrm{a}$ & $70.0 \mathrm{a}$ & $12.2 \mathrm{a}$ & $74.0 \mathrm{a}$ & $12.8 \mathrm{ab}$ \\
\hline 10 & $* / \mathrm{E} / \mathrm{V} / *$ & $184.9 \mathrm{a}$ & $146.0 \mathrm{a}$ & $76.8 \mathrm{a}$ & $13.3 \mathrm{a}$ & $78.8 \mathrm{a}$ & $14.1 \mathrm{ab}$ \\
\hline 0 & $\mathrm{~V} / \mathrm{E} / \mathrm{V} / \mathrm{E}$ & $188.9 \mathrm{a}$ & $147.6 \mathrm{a}$ & $57.5 \mathrm{~b}$ & $8.6 \mathrm{~b}$ & $75.5 \mathrm{a}$ & $10.8 \mathrm{~b}$ \\
\hline 0 & $* / \mathrm{E} / \mathrm{V} / *$ & $196.7 \mathrm{a}$ & $137.1 \mathrm{a}$ & $75.0 \mathrm{a}$ & $16.4 \mathrm{a}$ & $80.5 \mathrm{a}$ & $17.5 \mathrm{a}$ \\
\hline
\end{tabular}

${ }^{\mathrm{w}}$ Total rot incidence from total harvest rot from Botrytis cinerea, Rhizopus spp., Penicillium spp., and Aspergillus spp. Each large plot consisted of 24 vines, with a total of 100 clusters per plot being assessed. Values are means of four replicates. Within a given year, values followed by the same letter are not significantly different based on Fisher's protected least significant difference $(\alpha=0.05)$. Uppercase letters indicate significance at $\alpha=0.01$.

${ }^{x}$ Gibberellic acid (GA) applications were carried out at bloom.

${ }^{\text {y }}$ Botrytis spp.-specific fungicides applied at bloom/precluster closure/veraison/preharvest, where $\mathrm{E}=$ Elevate at $1.1 \mathrm{~kg} / \mathrm{ha}$ and $\mathrm{V}=\mathrm{Vangard}$ at $0.7 \mathrm{~kg} / \mathrm{ha}$; * indicates no fungicide was applied.

${ }^{\mathrm{z}}$ Severity was rated using the Barratt-Horsfall scale (14) and was converted to percent area infected using Elanco conversion tables (25). 
yield (total cluster weight per vine) in 3 of 4 years. Total yield was only significantly reduced by some GA treatments after four consecutive years of application to the same vines $(P=0.0326$; Table 5). However, the most consistent significant yield effect was the reduction in individual cluster weight associated with GA application in all years of the experiment when compared with the sprayed check (Table 5; Fig. 4). This trend can be primarily traced to the reduction in berries per cluster, an intended effect largely responsible for the associated reductions in compactness and bunch rot.

\section{Discussion}

Our previous study showed that cluster compactness, measured as berries per centimeter, plays an important role in the development of bunch rot on Vignoles, thereby supporting the hypothesis that modifying cluster architecture to reduce compactness is a prudent strategy to control the disease on this cultivar (13). In this study, applications of GA reduced berries per centimeter and bunch rots in Vignoles and, to a lesser extent, in Chardonnay, over three consecutive years. However, the magnitude of GA effects often depended on the timing and rate of application. Bloom GA applications were always more effective at reducing compactness and bunch rots than prebloom applications. These observations on the effectiveness of GA at reducing cluster compactness and, by extension, bunch rot severity fully concur with earlier studies using seedless and seeded grape cultivars $(3,5,10,18,22,34)$ and provide an impetus for reassessing the incorporation of GA into integrated programs for management of bunch rot in the eastern United States.

The hypothesis that reducing cluster compactness results in reduction in bunch rot intensity was investigated with regression analysis. Our results demonstrated conclusively that reducing cluster compactness resulted in a significant reduction in the incidence of bunch rot for both Chardonnay and Vignoles, although the rates of decline for Vignoles varied across the years (Fig. 1). The regression models further showed that Chardonnay clusters with about 5 berries per centimeter (i.e., the intercept) would not suffer any bunch rot but that low levels of bunch rot incidence will occur on Vignoles, regardless of the degree of cluster compactness. This outcome is not unrealistic, nor do the findings on Vignoles contradict our recent studies in which we reported that clusters with about 6 berries per centimeter would not suffer bunch rot (13). First, regression models in the present study are based on bunch rot incidence rather than disease severity. Indeed, regression analyses based on bunch rot severity concur with those of our earlier studies (13) even though berries per centimeter accounted for less variability in bunch rot severity for Chardonnay than it did for incidence (data not shown).

When we examine the amount of variation in rot severity explained by compactness for Vignoles, the $r^{2}$ value of 0.89 in the previous study (13) compares well with those obtained in this study $(0.88,0.59$, and 0.84 in 2006, 2007, and 2008, respectively). Likewise, the $y$-intercept estimates of 4 to 6.5 berries per centimeter in this study are within the standard error of the estimate $(6 \pm$ 2.75 , mean \pm standard error) established in the previous study. However, the estimates of the regression slopes in the present study (2.26, 1.67, and 2.04 for 2006, 2007, and 2008, respectively) are only about one-half the 4.15 established in the previous study. These observations are important for two reasons. First, the consistency in the estimates of the intercept parameter and the amount of variation in bunch rot severity accounted for by cluster compact-
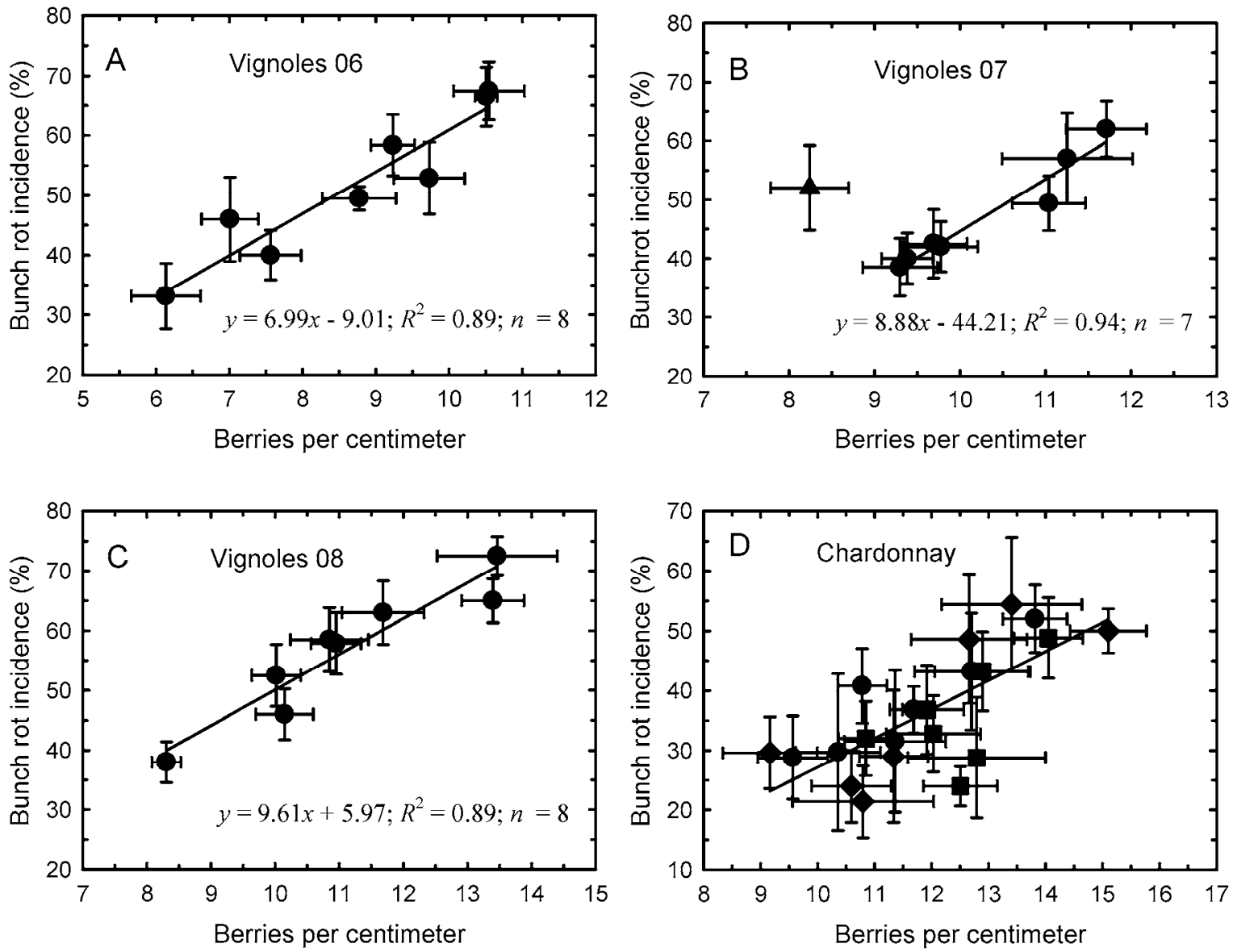

Fig. 1. Relationship between cluster compactness (berries per centimeter) and bunch rot incidence in field plots of $A, B$, and $C$, Vignoles and $D$, Chardonnay grape berries near Lake Erie, PA in the 2006 to 2008 seasons. Values are means and standard errors of eight replicate plots for Vignoles in A-C or five replicate plots for Chardonnay while the line indicates the fitted regression of disease incidence against berries per centimeter. Regression analysis indicated that years had separate slopes in each year for Vignoles but not for Chardonnay, for which a single model $\left(y=4.84 x-21.2 ; R^{2}=0.53 ; n=21\right)$ was subsequently fitted. An outlier in Vignoles data for 2007 indicated with a triangular symbol was not included in the regression analysis. 
ness obtained from separate unrelated studies that were separated in time (the estimate reported in 2009 were based on studies carried out in 2004) indicates a high level of reliability in the data. Second, the discrepancy observed in estimates of the rate parameter can be explained with epidemiological principles. That is, the lower estimates of the rate parameter obtained in the present study can be accounted for by lower levels of bunch rot severity as a result of fungicide use. These differences in estimates of the slope parameters between the two studies also suggest that the effects of cluster compactness are more pronounced when no fungicides were used.

The mechanisms by which cluster loosening occurs are not fully understood. Two mechanisms are thought to play a key role depending on the time of GA application; reductions in fruit set (bloom application), or increases in cluster length (prebloom appli- cation). Some researchers have suggested that GA reduces pollen germination (33), limiting fertilization. Also, the stimulation of vegetative growth by GA at prebloom may increase cluster length, whereas the stimulation of vegetative growth at bloom may increase competition for carbohydrates between flowers and other organs, thereby increasing flower and fruitlet abortion (4). Regardless of the actual pathway, the outcome of these mechanisms is to reduce cluster compactness. In this study, applications of GA made at bloom were directed at reducing fruit set in order to loosen clusters. In Chardonnay, fruit set was reduced by 16 to $29 \%$ in 2006 and 2007, and reductions consistently increased with increasing rates. Consequently, compactness was significantly reduced by all bloom treatments in 2006 and 2007. This was in sharp contrast with 2008 , in which only the high rate reduced fruit set by a modest $3 \%$, with a concomitant reduction in cluster compactness pre-
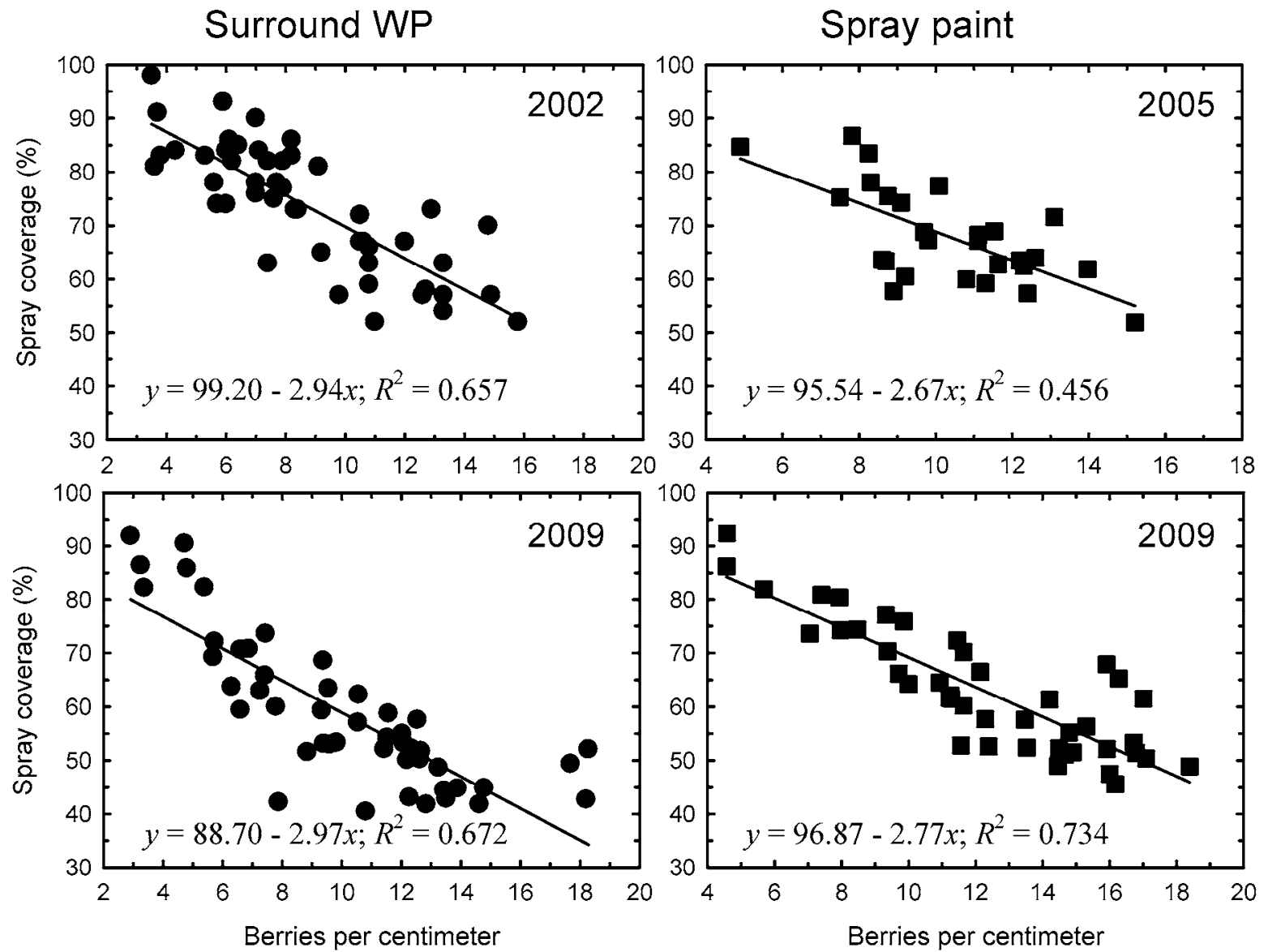

Fig. 2. Effect of cluster compactness (berries per centimeter) on spray penetration and coverage within clusters of Vignoles grape in experiments using spray powder or paint. Values indicate spray penetration measured as percentage of berries covered with spray powder for 48 clusters of varying compactness in both the 2002 and 2009 experiments, or with spray paint for 28 and 44 clusters in 2005 and 2009, respectively. The line represents a linear regression relating spray penetration (y) with berries per $\mathrm{cm}(x)$ fitted to the values as indicated in the equations within each graph.

Table 5. $F$ test statistics for analysis of variance testing the effects of gibberellic acid $\left(\mathrm{GA}_{3}\right)$ application on various return yield components of Vignoles grape near Lake Erie, PA

\begin{tabular}{|c|c|c|c|c|c|c|c|}
\hline \multirow[b]{2}{*}{ Variable $^{\mathrm{y}}$} & \multirow[b]{2}{*}{$d f^{\mathbf{z}}$} & \multicolumn{2}{|c|}{2007} & \multicolumn{2}{|c|}{2008} & \multicolumn{2}{|c|}{2009} \\
\hline & & $F$ & $P$ & $F$ & $P$ & $\boldsymbol{F}$ & $P$ \\
\hline Total buds per plot (single vine) & 9 & 0.73 & 0.680 & 1.03 & 0.425 & 1.691 & 0.200 \\
\hline Clusters per bud & 9 & 0.74 & 0.675 & 3.52 & $<0.001$ & 2.245 & 0.113 \\
\hline Clusters per shoot & 9 & 1.26 & 0.273 & 4.03 & $<0.001$ & 0.320 & 0.810 \\
\hline Total number of clusters per plot & 9 & 0.99 & 0.458 & 1.99 & 0.053 & 0.410 & 0.748 \\
\hline Total cluster weight $(\mathrm{Kg})$ & 9 & 1.13 & 0.353 & 1.08 & 0.388 & 3.530 & 0.033 \\
\hline Individual cluster weight $(\mathrm{g})$ & 9 & 3.39 & 0.002 & 2.80 & 0.007 & 16.873 & $<0.001$ \\
\hline Grams of fruit per bud & 9 & 1.07 & 0.398 & 1.44 & 0.190 & 2.355 & 0.101 \\
\hline
\end{tabular}

y Total buds per plot (vine) were determined at the beginning of each season. All other parameters were determined after harvest and reflect effects of 2, 3 , and 4 years of consecutive seasons of GA application to the same vines.

${ }^{\mathrm{z}}$ Data were analyzed for all 10 treatments except for 2009 , in which case $\mathrm{df}=3$ because data were analyzed only for 4 of the 10 treatments. 
sumably resulting from a $13 \%$ lengthening of the cluster in that treatment relative to the check. In Vignoles, fruit set was reduced by all bloom treatments in all years, with reductions ranging from 17 to $52 \%$, and bloom sprays appeared to have a greater and more consistent effect on fruit set in Vignoles than Chardonnay. These results, therefore, support the hypothesis that bloom applications of GA reduce cluster compactness mostly by reducing fruit set and may explain why GA applications at this time were more effective and consistent at reducing cluster compactness on Vignoles compared with Chardonnay.

Prebloom GA applications were intended to reduce compactness and bunch rot, presumably by increasing cluster length. The target for timing of prebloom applications was 2 weeks before the beginning of bloom, when inflorescences are rapidly growing $(10,22)$. In Chardonnay, prebloom GA treatments resulted in modest increases in cluster length (5 to $20 \%$ when compared with the nontreated check) in most but not all treatments. Likewise, modest increases in cluster length (5 to $13 \%$ ) from prebloom GA treatments were noted in Vignoles in 2006 and 2008 but not in 2007. Instead, more like bloom applications, prebloom applications in 2007 reduced fruit set by 9 to $28 \%$, with up to $21 \%$ reduction in compactness at the highest rate $(25 \mathrm{ppm})$, which was as effective as bloom applications. These results provided evidence of some overlap between effects on fruit set reduction and cluster lengthening from GA application shortly before and during bloom, an effect also noted by an earlier study with Vignoles (3). Indeed, cluster length was modestly increased (by between 4 and $21 \%$ relative to the nontreated check) in all GA bloom treatments to Chardonnay in all years.
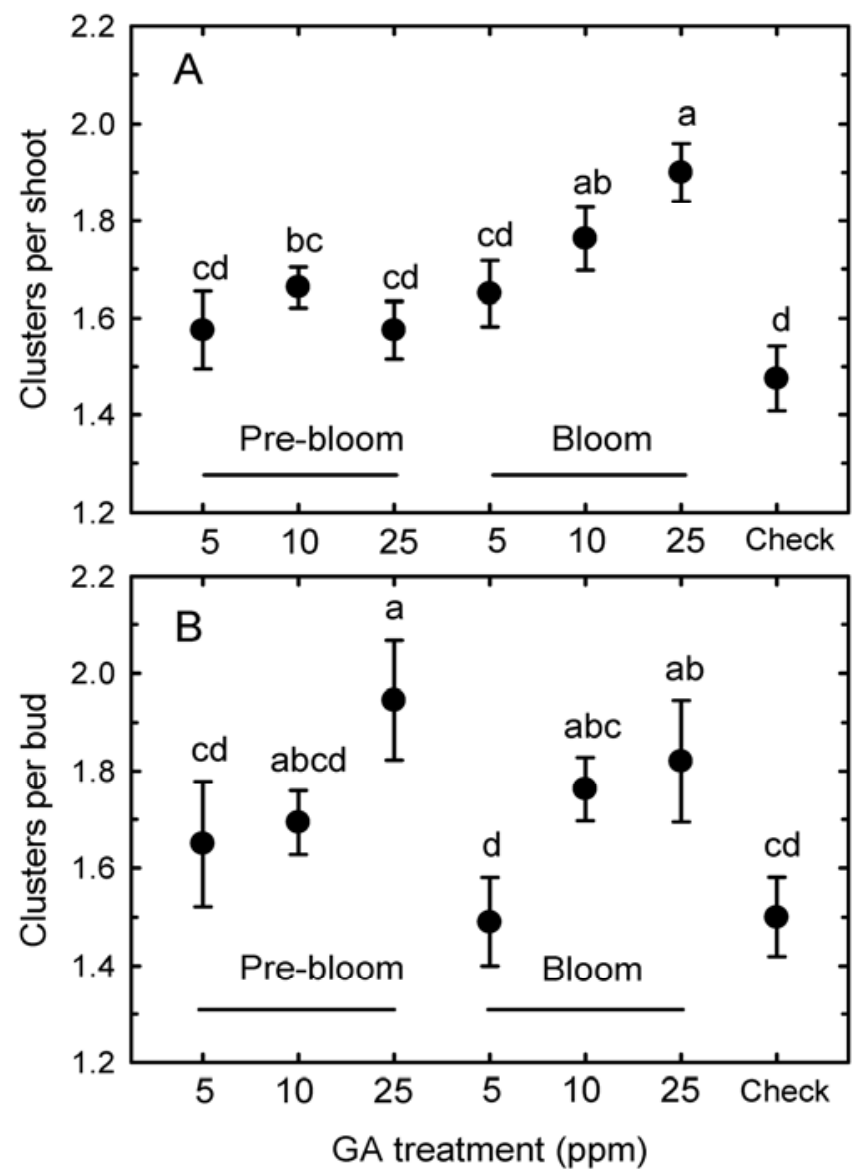

Fig. 3. Effect of gibberellic acid (GA) application on return yield components $\mathbf{A}$, the number of clusters per shoot and $\mathbf{B}$, number of clusters per bud after three consecutive years of GA application (i.e., data from 2008) on Vignoles grape near Lake Erie, PA. Values are mean and standard errors of eight replicate plots, and means followed by the same letter are not statistically different based on Fisher's protected least significant difference $(\alpha=0.05)$.
The consistency with which GA applications can be accurately timed has tremendous practical importance and may have been a factor contributing to the superior efficacy of bloom applications in this study. In this study, we intended to apply prebloom GA treatments 2 weeks before bloom. Each year, the estimated timing of 2 weeks before bloom was based on historical data collected since 1999 on the average date for the beginning of bloom (i.e., at the Eichhorn-Lorenz phenological stage 19) (9). However, Vignoles bloom date at our location has varied by as many as 16 days (from 14 to 30 June) over the past 10 years. Bloom commenced several days earlier (2007 and 2008) or several days later (2009) than the estimated date, resulting in mistiming of prebloom applications. Therefore, optimal timing for prebloom applications was difficult to predict accurately in the extremely variable spring climate along the shores of Lake Erie. By comparison, progression of bloom is easier to monitor and mid- to late-bloom applications (i.e., at Eichhorn-Lorenz stages 23 to 25 ) are less apt to be mistimed.

One of the mechanisms by which cluster compactness is thought to affect bunch rot severity is by influencing fungicide efficacy through its impacts on spray penetration within a cluster (13). Our data show that, during ripening, when fruit are most susceptible to rots, potential spray coverage of individual berries is reduced as compactness increases, eventually becoming limited to the outside of the cluster (40 to $50 \%$ of berry surfaces) as compactness approaches about 15 to 18 berries per centimeter (Fig. 2). Reduced spray penetration can result in reduced efficacy against bunch rot,
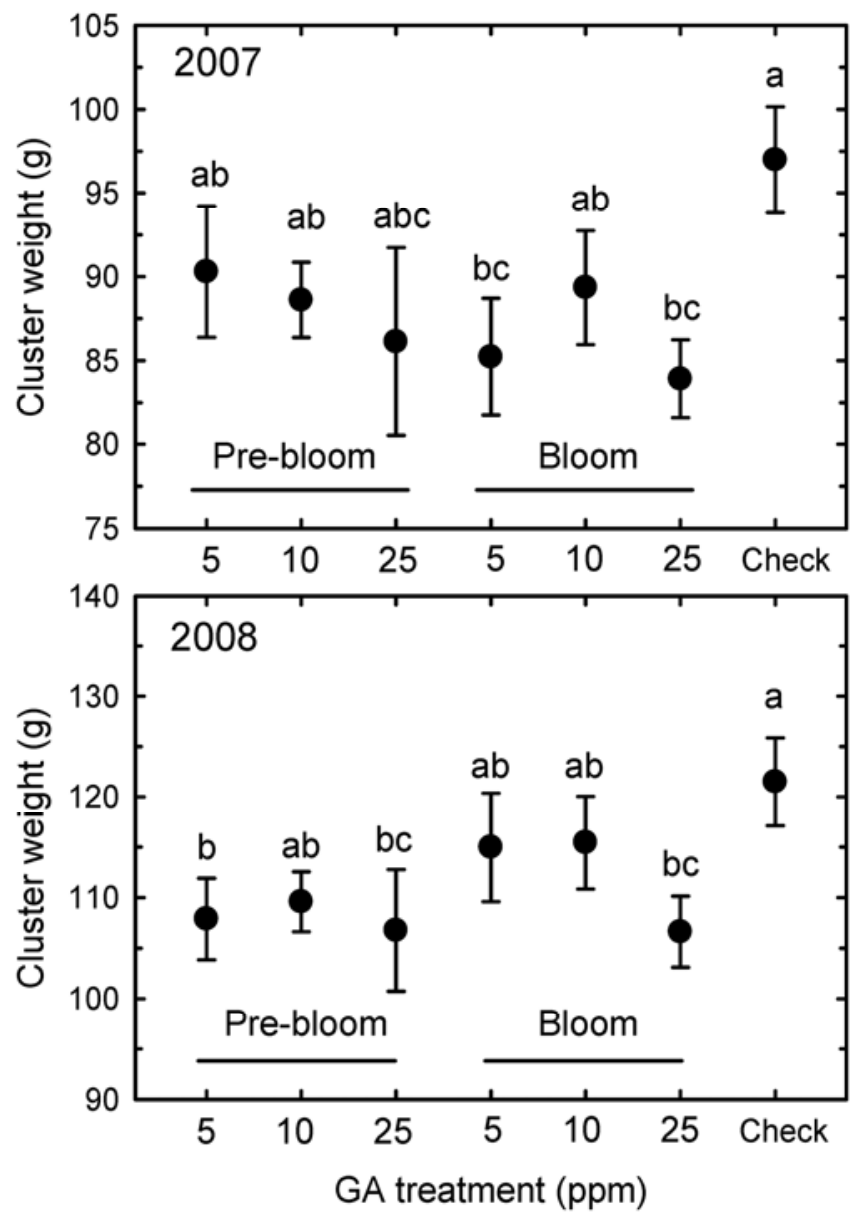

Fig. 4. Effect of gibberellic acid (GA) application on components of return yield for Vignoles measured as cluster weight 2 and 3 years after vines were treated with various rates of GA. The same GA treatments were applied to the same vines over four consecutive years starting in 2006 to 2009 and data were obtained at the end of the 2007, 2008, and 2009 seasons. Only data from 2007 and 2008 are presented but those from 2009 are similar. Values are mean and standard errors of eight replicate plots, and means followed by the same letter are not statistically different based on Fisher's protected least significant difference $(\alpha=0.05)$. 
especially for fungicides with a contact mode of action, even when full chemical programs for Botrytis spp. are applied. This led us to examine the hypothesis that, because GA reduces compactness of clusters, it would also improve spray penetration and efficacy of Botrytis spp.-specific fungicides. Support for this hypothesis is indicated in our data from Vignoles, where two Botrytis spp.specific fungicides alone failed to control rot incidence in all 3 years or rot severity in all but 2008 relative to the unsprayed check. Indeed, even four applications of the fungicides did not provide sufficient bunch rot control in years with high disease pressure such as 2006 and 2008 (Table 3). By contrast, when two fungicide sprays were applied to plots treated with GA at bloom, control of rot incidence and severity were equal to (in 2007) and often superior to (2006 and 2008) four fungicide sprays with no GA. In Chardonnay, which is somewhat less susceptible to bunch rots than Vignoles, four applications of Botrytis spp.-specific fungicides were consistently effective at reducing Botrytis bunch rot. However, two applications of fungicide did not control incidence of Botrytis disease in any year or severity in 2 of 3 years on this cultivar. As in Vignoles, the addition of GA-especially the bloom applications that were most effective at reducing compactnessimproved the effectiveness of the two-fungicide program, resulting in a significant control of rot incidence and severity equal to that obtained with four fungicide sprays. We cannot tease apart the relative contributions of improved spray penetration and lowered predisposition to infection resulting from reductions in compactness to the observed level of bunch rot intensity. Nevertheless, these data show that GA application can increase fungicide penetration and enhance the efficacy of these expensive materials, and that bunch rot control programs for compact cultivars that integrate cluster loosening tactics are less prone to fail than programs that rely solely on fungicides.

GA application has been associated with serious yield loss in some cultivars $(1,8)$ and this liability has greatly restricted its labeling on seeded wine grape. However, the negative effects of GA application appear to be associated with rates much higher than those tested in our study, and are often specific to timing and cultivar. In previous work by Feree et al. (10), bloom applications of GA at $45 \mathrm{ppm}$ to Vignoles and Pinot Gris were shown to be a potentially valuable component of a bunch rot management program. However, yield reductions were associated with GA application at this rate in some years in that study. For example, significant yield reduction occurred in Vignoles in 1 of 4 years but could not be traced to lower cluster weights. In our trials with Vignoles, GA was not associated with a reduction in return clusters per vine, per shoot, or per bud over four consecutive years of application to the same vines (Table 5), and there was no yield reduction from GA bloom applications over 2 years in larger, 24-vine plots (Table 4). However, in single-vine plots, there were consistent reductions in individual cluster weights among GA treatments on Vignoles in all years and on Chardonnay in 2006 and 2007. This was an immediate, intended effect mostly associated with bloom application of GA, rather than a "year-after" effect, and it raises the potential for minimizing GA-associated yield reduction in these cultivars by modest increases in bud number. That is, whereas some reduction in cluster weight can occur as a result of GA applications, this is sufficiently compensated for by increasing the number of clusters per vine that can be supported. Moreover, there were no detectable carryover effects of GA applications for up to 3 years. Taken together, these results indicate that the risk of yield loss from GA application in Vignoles is negligible for rates not exceeding $25 \mathrm{ppm}$.

Eastern wine grape growers need more options to improve the consistency of bunch rot control "in spite of the weather." Over 3 years, the use of a single, inexpensive GA application at bloom to cvs. Vignoles (25 ppm) and Chardonnay (5 ppm) produced less compact clusters with consistently less bunch rot while showing potential for reducing reliance on more expensive, resistance-prone chemical fungicides. Evidence of adverse year-after effects on return fruitfulness is lacking, and yield reduction within a given year can be more easily traced to the intended effects on fruit set reduction. These effects may be less important when compared with the effects of bunch rots, especially sour rots, on wine quality $(26,27)$, in wet harvest seasons because the ideal total plot weight can be achieved by allowing more light clusters per vine $(31,32)$. These results strongly support the use of GA in the integrated management of bunch rot on Vignoles and Chardonnay in the northeastern United States. Nevertheless, despite the generally positive findings here, further integration of GA application for bunch rot management in the region should proceed with caution because the effects of GA can be quite variable depending on cultivar and timing.

\section{Acknowledgments}

We thank the Lake Erie Regional Grape Program and the New York State Wine and Grape Foundation for financial support for this project; and J. Griggs, M. Wheeler, L. K. Collins-Hed, and B. Alcorn for essential field and laboratory support.

\section{Literature Cited}

1. Blaha, J. 1963. Influence of gibberellic acid on the grapevine and its fruit in Czechoslovakia. Am. J. Enol. Vitic. 14:161-163.

2. Bukovac, M. J., Larson, R. D., and Bell, H. K. 1960. Effect of gibberellin on berry set and development of Concord grape. Q. Bull. Mich. Agric. Exp. Stn. 42:503-510.

3. Cahoon, G. A., and Scurlock, D. M. 1992. Effects of gibberellic acid $\left(\mathrm{GA}_{3}\right)$ on cluster size and density of Vignoles grapes. Am. J. Enol. Vitic. 43:115.

4. Caspari, H. W., Lang, A., and Alspach, P. 1998. Effects of girdling and leaf removal on fruit set and vegetative growth in grape. Am. J. Enol. Vitic. 49:359-366.

5. Christodoulou, A. J., Weaver, R. J., and Pool, R. M. 1968. Relation of gibberellin treatment to fruit set, berry development, and cluster compactness in Vitis vinifera grapes. J. Am. Soc. Hortic. Sci. 92:301-310.

6. Coombe, B. G. 1959. Fruit set and development in seeded grape varieties as affected by defoliation, topping, girdling, and other treatments. Am. J. Enol. Vitic. 10:85-100.

7. Dass, H. C., and Randhawa, G. S. 1968. Effect of gibberellin on 'Golden Queen' grape, a vinifera-labrusca hybrid. Am. J. Enol. Vitic. 19:52-55.

8. Dass, H. C., and Randhawa, G. S. 1968. Response of certain seeded Vitis vinifera varieties to gibberellin application at post-bloom stage. Am. J. Enol. Vitic. 19:56-62.

9. Eichhorn, K. W., and Lorenz, D. H. 1977. Phänologische Entwicklungsstadien der Rebe. Nachrichtenbl. Dtsch. Pflanzenschutzdienstes (Braunschweig) 29:119-120.

10. Ferree, D. C., Ellis, M. A., McArtney, S. J. Brown, M. V., and Scurlock, D. M. 2003. Comparison of fungicide, leaf removal and gibberellic acid on development of grape cluster and Botrytis bunch rot of 'Vignoles' and 'Pinot Gris'. Small Fruits Rev. 2:3-19.

11. Funt, R. C., and Tukey, L. D. 1977. Influence of exogenous daminozide and gibberellic acid on cluster development and yield of the 'Concord' grape. J. Am. Soc. Hortic. Sci. 102:509-514.

12. Haeseler, C. W., and Beelman, R. B. 1977. Vine performance and wine quality for seventeen white wine grape cultivars grown in Erie County, Pennsylvania, for three growing seasons. Am. J. Enol. Vitic. 28:223-227.

13. Hed, B., Ngugi, H. K., and Travis, J. W. 2009. Relationship between cluster compactness and bunch rot in Vignoles grapes. Plant Dis. 93:1195-1201.

14. Horsfall, J. G., and Barratt, R.W. 1945. An improved grading system for measuring plant disease. (Abstr.) Phytopathology 35:655.

15. Howell, G. S., Miller, D. P., Edson, C. E., and Striegler, R. K. 1991. Influence of training system and pruning severity on yield, vine size and fruit composition of Vignoles grapevines. Am. J. Enol. Vitic. 42:191-198.

16. Kaps, M. L., and Odneal, M. B. 2001. Grape cultivar performance in the Missouri Ozark region. J. Am. Pomol. Soc. 55:34-44.

17. Kiyomoto, R. K. 1995. Testing wine grapes for hardiness and yield helps Connecticut growers select varieties. Front. Plant Sci. 47:7-8.

18. Miele, A., Weaver, R. J., and Johnson, J. 1978. Effect of potassium gibberellate on fruit-set and development of Thompson Seedless and Zinfandel grapes. Am. J. Enol. Vitic. 29:79-82.

19. Nagao, A., Shiohara, H., Ueno, N., and Sato, M. 1997. Effects of gibberellic acid spraying on peduncle elongation of Riesling berry clusters. Am. J. Enol. Vitic. 48:126.

20. Nelson, K. E., and Ough, C. S. 1966. Chemical and sensory effects of microorganisms on grape musts and wine. Am. J. Enol. Vitic. 17:38-47.

21. Pearson, R. C., and Riegel, D. G. 1983. Control of Botrytis bunch rot of ripening grapes: timing applications of the dicarboximide fungicides. Am. J. Enol. Vitic. 34:167-172.

22. Peterson, D. V. 1987. Cluster-thinning and growth regulator effects on fruit development, juice quality, and vine growth of selected grape cultivars. $\mathrm{Ph}$.D. thesis, Pennsylvania State University, State College.

23. Petgen, M. 2005. Gibberellin use for quality control. Schweiz. Z. ObstWeinbau 141:6-9 
24. Read, P. E., Gu, S., Gamet, S., and Schild, J. 2004. Testing of varieties and selections under challenging climatic conditions. Acta Hortic. 652:65-71.

25. Redman, G. E., King, E. P., and Brown, I. F., Jr. 1969. Elanco Conversion Tables for Barratt-Horsfall Rating Numbers. Elanco Products Co., Indianapolis, IN.

26. Siegfried, W. 2007. Gibberellin trials 2007 in wine production. Schweiz. Z. Obst- Weinbau 144:4-7.

27. Spring, J. L., and Viret, O. 2009. Influence of thinning methods on yield, bunch morphology, grey and sour rot, and wine quality of Pinot noir. Rev. Suisse Vitic. Arboric. Hortic. 41:95-101.

28. Staraz, M. di V., Laucou, V., Boursiquot, J. M., Lacombe, T., Varès, D., Gerber, S., Boselli, M., This, P., Peterlunger, E., di Gaspero, G., and Cipriani, G. 2009. The kingroup of the cultivar 'Chardonnay' revealed. Acta Hortic. 827:233-238.

29. Vail, M. E., and Marois, J. J. 1991. Grape cluster architecture and the susceptibility of berries to Botrytis cinerea. Phytopathology 81:188-191.
30. Watt, A. M., Dunn, G. M., May, P. B., Crawford, S. A., and Barlow, E. W. R. 2008. Development of inflorescence primordia in Vitis vinifera L. cv. Chardonnay from hot and cool climates. Aust. J. Grape Wine Res. 14:46-53.

31. Weaver, R. J., Kasimatis, A. N., and McCune, S. B. 1962. Studies with gibberellin on wine grapes to decrease bunch rot. Am. J. Enol. Vitic. 13:7882 .

32. Weaver, R. J., and McCune, S. B. 1959. Effect of gibberellin on seeded Vitis vinifera and its translocation within the vine. Hilgardia 28:625-645.

33. Weaver, R. J., and McCune, S. B.1960. Further studies with gibberellin on Vitis vinifera grapes. Bot. Gaz. 121:155-162.

34. Weaver, R. J., and Pool, R. M. 1971. Thinning 'Tokay' and 'Zinfandel' grapes by bloom sprays of gibberellin. J. Am. Soc. Hortic. Sci. 96:820822.

35. Zitter, S. M., and Wilcox, W. F. 2004. Ontogenic, physical, and cultural factors affecting the initiation and spread of Botrytis bunch rot of grapes. In: XIII Botrytis Symp. Antalya, Turkey. 